\title{
Pituitary function in children with hydrocephalus before and after the first shunting operation
}

\author{
Tuija Löppönen ${ }^{1}$, Anna-Liisa Saukkonen ${ }^{1}$, Willy Serlo ${ }^{1}$, Päivi Tapanainen ${ }^{1}$, Aimo Ruokonen ${ }^{2}$, Peter Lanning ${ }^{3}$ \\ and Mikael Knip ${ }^{4}$ \\ Departments of ${ }^{1}$ Pediatrics, ${ }^{2}$ Clinical Chemistry, and ${ }^{3}$ Radiology, University of Oulu, Oulu, Finland and ${ }^{4}$ Medical School, University of Tampere, \\ Finland and Department of Pediatrics, Tampere University Hospital, Tampere, Finland
}

(Correspondence should be addressed to T Löppönen, Department of Pediatrics, University of Oulu, Kajaanintie 52 A, FIN-90220 Oulu, Finland)

\begin{abstract}
Objective: Children with shunted hydrocephalus experience slow linear growth in prepuberty, accelerated pubertal maturation and a reduced final height. A substantial proportion of these patients have a poor growth hormone $(\mathrm{GH})$ response to stimulation and reduced pituitary volume. The basic mechanisms behind these phenomena are still unknown, but one can hypothesize that an unphysiological intracranial pressure (ICP) may be involved. This study was undertaken to investigate the effect of increased ICP on pituitary function.

Design: Twenty-one children (nine males) aged 4 months to 15 years were evaluated for pituitary function before and after their first shunting operation.

Methods: A clinical examination was performed, bone age was determined and a combined pituitary stimulation test was performed to evaluate $\mathrm{GH}$, luteinizing hormone, follicle-stimulating hormone, cortisol, thyrotropin and prolactin secretion.

Results: GH concentrations were significantly higher 10 and $15 \mathrm{~min}$ before the operation $(P=0.04$ and $P=0.03$ respectively) than after it. The basal levels of insulin-like growth factor-I (IGF-I) tended to be higher before the operation than afterwards and those of its binding protein-3 (IGFBP-3) were significantly so $(P<0.01)$.

Conclusions: The higher GH response to GH releasing hormone and circulating IGFBP-3 levels in children with hydrocephalus before compared with after their first shunting operation raise the possibility that the reduced GH secretion and retarded linear growth observed in children with shunted hydrocephalus may be a consequence of decreased ICP and/or the lack of physiological pressure variations.
\end{abstract}

European Journal of Endocrinology 138 170-175

\section{Introduction}

Children with shunted hydrocephalus may have endocrine abnormalities affecting their growth and puberty (1-4). Raised intracranial pressure (ICP) has been perceived as a possible cause of pituitary dysfunction (5), and there are a few case reports on the relationship between this and hormonal disturbances. Fiedler \& Krieger (6) have shown that two out of three female patients with aquaductal stenosis had abnormal cortisol and growth hormone $(\mathrm{GH})$ responses in an insulin tolerance test which normalized after the operation. Caporal et al. (7) reported on a 28-year-old female presenting with primary amenorrhea and isolated gonadotropin deficiency which showed complete remission after shunting, while a female patient with a convexity meningeoma studied by Kulali et al. (8) experienced an increase in plasma gonadotropins and the reappearance of regular menstrual cycles after surgery. In contrast, a male patient with hydrocephalus and delayed puberty did not show any changes in gonadotropin or sex hormone concentrations or in his clinical characteristics after a shunting operation.

To evaluate the possible effect of increased ICP on pituitary function, we performed a combined pituitary stimulation test on 21 children with newly diagnosed hydrocephalus before their first shunting operation and another test about 6 weeks after surgery.

\section{Subjects and methods}

\section{Subjects}

The population comprised 21 consecutive patients (9 males, 12 females), who underwent their first shunting operation for hydrocephalus at the Department of Pediatrics, Oulu University Hospital, Oulu, Finland, during the years 1992-1995. After a clinical examination, a combined pituitary stimulation test was performed 
before the first shunting operation and repeated after the operation. Informed consent was obtained from the subjects and/or their parents. The research was conducted according to the Declaration of Helsinki. Patients with congenital spina bifida and hydrocephalus were excluded because they underwent several operations in the neonatal period and it was not considered ethically justified to take extra blood samples before the operation at such a young age. Individual details regarding age, sex, symptoms and signs, duration of symptoms and etiology are given in Table 1. The mean age of the patients was 5.2 years (range 0.3 to 15.3 years), and there were no differences in this respect between the male and female patients ( 5.1 years (range 0.4 to 14.4 years) vs 5.2 years (range 0.3 to 15.3 years) respectively). Seventeen subjects were prepubertal and four pubertal (cases 18-21). One girl (case 8) had an androgen insensitivity syndrome and was excluded from the analyses of gonadotropins and sex hormones. Most of the shunts installed were of the Hakim-Cordis type $(n=14)$, but Orbis-Sigma shunts were used more frequently in recent cases $(n=7)$. The majority of the shunts were ventriculoperitoneal $(n=14)$ and a minority cystoperitoneal $(n=6)$, and in one patient both shunts were installed.

The etiology of hydrocephalus was assessed according to a modification of the classification proposed by Amacher \& Wellington (9) based on the initial findings at computer tomography or magnetic resonance imaging. The causes were congenital in 12 patients $(57 \%)$ and acquired in 9 cases $(43 \%)$. The mean time between the first and the second visit was 6 weeks (range 2 to 15 weeks).

\section{Methods}

All the patients were examined by one of the authors (T L). Height was measured to the nearest $1.0 \mathrm{~mm}$ with a Harpenden wall-mounted stadiometer in the case of the patients who were able to stand, and in a recumbent position in the younger patients. Weight was measured to the nearest $0.1 \mathrm{~kg}$ with an electronic scale and head circumference to the nearest $1.0 \mathrm{~mm}$ with a metallic tape measure. The relative height, relative weight and relative head circumference were assessed from Finnish growth charts $(10,11)$. The target height was calculated as follows: target height standard deviation score $(\mathrm{SDS})=\{$ [height (centimetres) of mother+father $] / 2-$ $171\} / 10$ (12). The target height deficit represents the difference between the target height and relative height. Data on parental height were collected by means of a questionnaire. The stage of puberty was assessed according to Tanner \& Whitehouse (13). If there were no signs of puberty (pubic hair 1 and genitals 1 or pubic hair 1 and breast 1), the subjects were classified as prepubertal.

Bone age was evaluated by the method of Greulich \& Pyle on the basis of a radiograph of the left hand and wrist (14) and by the method of Elgenmark in the case of patients younger than 2 years of age (15).

A combined stimulation test with GH-releasing hormone (GHRH), corticotropin-releasing hormone

Table 1 Age, sex, symptoms and signs, duration of symptoms and diagnosis in the 21 hydrocephalic patients before their first shunting operation.

\begin{tabular}{|c|c|c|c|c|c|}
\hline Patient & $\begin{array}{c}\text { Age } \\
\text { (years) }\end{array}$ & Sex & $\begin{array}{c}\text { Symptoms and signs before } \\
\text { the first operation }\end{array}$ & $\begin{array}{c}\text { Duration of } \\
\text { symptoms (months) }\end{array}$ & Diagnosis \\
\hline 1 & 0.3 & $\mathrm{~F}$ & Increased head circumference & $<3$ & Infantile obstructive $\mathrm{HC}$ \\
\hline 2 & 0.4 & $\mathrm{~F}$ & Increased head circumference & $<1$ & Intracranial anomaly \\
\hline 3 & 0.4 & $\mathrm{~F}$ & Increased head circumference & $<3$ & Infectious (calmette tbc) \\
\hline 4 & 0.4 & M & Increased head circumference & $<3$ & Right ventricular cyst \\
\hline 5 & 0.5 & $\mathrm{~F}$ & Increased head circumference & $<3$ & Cyst of Dandy Walker \\
\hline 6 & 0.6 & M & Increased head circumference & $<3$ & Infantile obstructive $\mathrm{HC}$ \\
\hline 7 & 0.6 & $\mathrm{~F}$ & Increased head circumference & $<3$ & $\begin{array}{l}\text { Transposition the great arteries } \\
\text { (corrected), thrombosis of the vena cava }\end{array}$ \\
\hline 8 & 1.3 & $\mathrm{~F}$ & Testicular feminization, MR & $>12$ & Intracranial anomaly \\
\hline 9 & 1.4 & M & Cranial fracture & $<1$ & Right arachnoidal cyst \\
\hline 10 & 2.5 & M & Increased head circumference & $6-12$ & Prematurity (GA 33 weeks) \\
\hline 11 & 4.4 & M & Headache for 6 months, vertigo & $6-12$ & Infantile obstructive $\mathrm{HC}$ \\
\hline 12 & 4.8 & $\mathrm{~F}$ & Retarded psychomotor development & $>12$ & Left arachnoidal cyst \\
\hline 13 & 5.4 & $\mathrm{~F}$ & $\begin{array}{l}\text { Vomiting in the mornings, papillar } \\
\text { stasis }\end{array}$ & $1-6$ & Cerebellar tumor \\
\hline 14 & 6.3 & M & Increased head circumference & $6-12$ & Prematurity (GA 31 weeks) \\
\hline 15 & 6.8 & $\mathrm{~F}$ & Headache, papillar stasis, squinting & $<1$ & Left arachnoidal cyst \\
\hline 16 & 7.5 & M & Headache & $6-12$ & Left arachnoidal cyst \\
\hline 17 & 8.3 & M & Headache, papillar stasis & $<1$ & Cerebellar tumor \\
\hline 18 & 12.1 & $\mathrm{~F}$ & $\begin{array}{l}\text { Routine tooth x-ray, destruction of the } \\
\text { sella turcica }\end{array}$ & $>12$ & Cerebral tumor \\
\hline 19 & 14.4 & M & Headache, papillar stasis & $>12$ & Infantile obstructive $\mathrm{HC}$ \\
\hline 20 & 14.8 & $\mathrm{~F}$ & Headache for 1 year, loss of vision & $>12$ & Cerebral tumor \\
\hline 21 & 15.3 & $\mathrm{~F}$ & Headache, papillar stasis, vertigo & $>12$ & Cerebral tumor \\
\hline
\end{tabular}

HC, hydrocephalus; GA, gestational age; MR, mental retardation; tbc, tuberculosis. 
(CRH), gonadotropin-releasing hormone (GnRH) and thyrotropin-releasing hormone (TRH) was performed at the time of the clinical evaluation before the first operation and at the first follow-up visit after surgery. The doses used were: GHRH (Geref, Serono, Geneva, Switzerland) $1 \mu \mathrm{g} / \mathrm{kg}, \quad \mathrm{CRH}$ (CRH Ovine, Bachem Feinchemikalien AG, Bubendorf, Switzerland) $1 \mu \mathrm{g} / \mathrm{kg}$, GnRH (Suprefact, Hoechst AG, Frankfurt am Main, Germany) $100 \mu \mathrm{g}$, and TRH (Relefact, Hoechst AG) $200 \mu \mathrm{g}$. Basal blood samples were taken for the analysis of $\mathrm{GH}$, adrenocorticotropin (ACTH), cortisol, luteinizing hormone (LH), follicle-stimulating hormone (FSH), thyrotropin (TSH), prolactin (PRL), insulin-like growth factor-I (IGF-I), IGF-binding protein-3 (IGFBP-3), testosterone and estradiol. After the injection of releasing hormones, blood samples were taken for $\mathrm{GH}$ at 10,15 , 20 and $60 \mathrm{~min}$, for ACTH at 10, 45 and $60 \mathrm{~min}$, for cortisol at 45 and $60 \mathrm{~min}$, for FSH at 30 and $60 \mathrm{~min}$ and for LH, TSH and PRL at 15 and $30 \mathrm{~min}$.

Serum concentrations of GH (Pharmacia Diagnostics, Uppsala, Sweden), IGFBP-3 (Diagnostic Systems Laboratories Inc., Webster, TX, USA), ACTH (Nichols Institute, San Juan Capistrano, CA, USA), cortisol, testosterone, estradiol-17 $\beta$ (Orion Diagnostica, Oulunsalo, Finland) and plasma IGF-I (Incstar Corporation, Stillwater, MN, USA) were determined by radioimmunoassay, serum LH, FSH and TSH by fluoroimmunoassay (Wallac Ltd, Turku, Finland) and serum PRL by a chemiluminescence assay (Ciba-Corning, Medfield, MA, USA) following the manufacturers' instructions.

\section{Statistical analysis}

The results were analyzed statistically by (a) crosstabulation and Chi-square statistics, (b) Student's t-test or paired sample $t$-test in the case of a normal distribution, and (c) the Mann-Whitney U-test or the Wilcoxon matched-pairs signed-rank test in the case of a skewed distribution or ordinal variables. The results are expressed as means with 95\% confidence intervals, unless otherwise indicated.

\section{Results}

There was an age-related variation in symptoms and signs and duration of symptoms among the 21 patients. Cases under the age of 1 year $(n=7)$ had all been referred to the hospital because of increased head circumference (Table 1), while the symptoms in the children aged 1-7 years included both increased head circumference and headache together with various other complaints. The duration of the symptoms had been more than 6 months in five cases $(63 \%)$. All the school-children (older than 7 years of age) had headache as their first symptom, and their symptoms had lasted for more than 6 months in all but one case (83\%). The symptoms had lasted for more than 6 months significantly more often in the school-children than among those under 1 year of age $(P<0.01)$.

The relative height of the patients tended to be lower than their target height, but not significantly so (target height deficit -0.07 SDS $(-0.53-0.38$ SDS $)$ ). Half the patients $(n=10)$ had a relative head circumference in excess of 2 SDS, the mean being 2.5 SDS (1.5-3.5 SDS). The relative head circumference decreased significantly after surgery (1.9 SDS (0.9-2.9 SDS), $P<0.01)$, as expected. Two children had an accelerated bone age (relative bone age $>2.0$ SDS) and two children a retarded bone age (relative bone age $<-2.0$ SDS).

There were three patients $(15 \%)$, cases 13,15 and 18, whose peak GH response to GHRH remained below $10 \mu \mathrm{g} / \mathrm{l}$ (range 2.7 to $4.5 \mu \mathrm{g} / \mathrm{l}$ ) before the operation. Two had a brain tumor (one with a cerebellar astrocytoma and the other with a tumor in the region of the brain stem), and the third an arachnoidal cyst in the middle of the skull base close to the pituitary gland. Two of these subjects still had a poor GH response in the second test, whereas the response normalized in one. When these patients were excluded, the GH area under the curve (AUC) tended to be higher before than after the operation $(3011 \mu \mathrm{g} / \mathrm{l} \cdot \mathrm{min} \quad(2089-3932 \mu \mathrm{g} / \mathrm{l} \cdot \min )$ vs $2295 \mu \mathrm{g} / \mathrm{l} \cdot \min (1629-2961 \mu \mathrm{g} / \mathrm{l} \cdot \min ), \quad P=0.08)$ and the mean GH levels were significantly higher at 10 and $15 \mathrm{~min}(31.5 \mu \mathrm{g} / \mathrm{l}(20.6-42.4 \mu \mathrm{g} / \mathrm{l}) \mathrm{vs} 20.5 \mu \mathrm{g} / \mathrm{l}$ $(11.9-29.2 \mu \mathrm{g} / \mathrm{l}), \quad P=0.04$ and $51.7 \mu \mathrm{g} / \mathrm{l} \quad(35.5-$ $67.9 \mu \mathrm{g} / \mathrm{l}) \quad$ vs $36.1 \mu \mathrm{g} / \mathrm{l} \quad(22.4-49.7 \mu \mathrm{g} / \mathrm{l}), \quad P=0.03$ respectively) (Fig. 1). The mean peak $\mathrm{GH}$ response to GHRH in the patients did not differ significantly before operation from the local reference range $(63.6 \mu \mathrm{g} / \mathrm{l}(41.8-85.5 \mu \mathrm{g} / \mathrm{l})$ vs $44.4 \mu \mathrm{g} / \mathrm{l}(28.5-60.2 \mu \mathrm{g} /$ l), $P=0.18$ ) based on short children with confirmed normal GH secretion (16). The same held true after the operation $\quad(57.1 \mu \mathrm{g} / \mathrm{l} \quad(39.7-74.4 \mu \mathrm{g} / \mathrm{l}) \quad$ vs $44.4 \mu \mathrm{g} / \mathrm{l}$ $(28.5-60.2 \mu \mathrm{g} / \mathrm{l}), P=0.29)$. When the youngest age group $(<1$ year of age, $n=7)$ and the oldest age group $(>12$ years of age, $n=3$ ) were compared, we observed that the decrease in the peak GH and GH AUC after the operation tended to be more marked in the younger group $(-26.3 \mu \mathrm{g} / \mathrm{l}$ (range $-116.0-29.83 \mu \mathrm{g} / \mathrm{l}$ ) vs $8.0 \mu \mathrm{g} / \mathrm{l}$ (range $-23.8-24.1 \mu \mathrm{g} / \mathrm{l}$ ), $P=0.31$ and $-1671 \mu \mathrm{g} / \mathrm{l} \cdot \mathrm{min}$ (range $-4974-672 \mu \mathrm{g} / \mathrm{l} \cdot \mathrm{min}$ ) vs $-59 \mu \mathrm{g} / \mathrm{l} \cdot \mathrm{min}$ (range $-1048-$ $1679 \mu \mathrm{g} / \mathrm{l} \cdot \mathrm{min}), P=0.14$ respectively).

Basal IGF-I concentrations tended to be higher before the operation than after it $(10.6 \mathrm{nmol} / \mathrm{l}(6.8-14.3 \mathrm{nmol} / \mathrm{l})$ vs $9.4 \mathrm{nmol} / \mathrm{l}(6.0-12.7 \mathrm{nmol} / \mathrm{l}), P=0.06)$, while the IGFBP-3 levels were significantly higher before the operation $(3.4 \mathrm{mg} / \mathrm{l}(2.5-4.2 \mathrm{mg} / \mathrm{l})$ vs $2.7 \mathrm{mg} / \mathrm{l}$ (1.9$3.4 \mathrm{mg} / \mathrm{l}), P<0.01)$. When the three patients with a poor $\mathrm{GH}$ response were excluded, the difference in IGFBP-3 concentrations remained significant $(3.0 \mathrm{mg} / \mathrm{l}$ (2.1$4.0 \mathrm{mg} / \mathrm{l})$ vs $2.5 \mathrm{mg} / \mathrm{l}(1.7-3.3 \mathrm{mg} / \mathrm{l}), P=0.02)$. There was no significant difference between the youngest and oldest age group in the mean decrease in IGF-I levels after the operation $(-0.5 \mathrm{nmol} / \mathrm{l}($ range $-1.9-1.2 \mathrm{nmol} / \mathrm{l})$ vs $-3.3 \mathrm{nmol} / \mathrm{l}$ (range $-13.2-6.0 \mathrm{nmol} / \mathrm{l}$ ), $P=0.43$ ), 


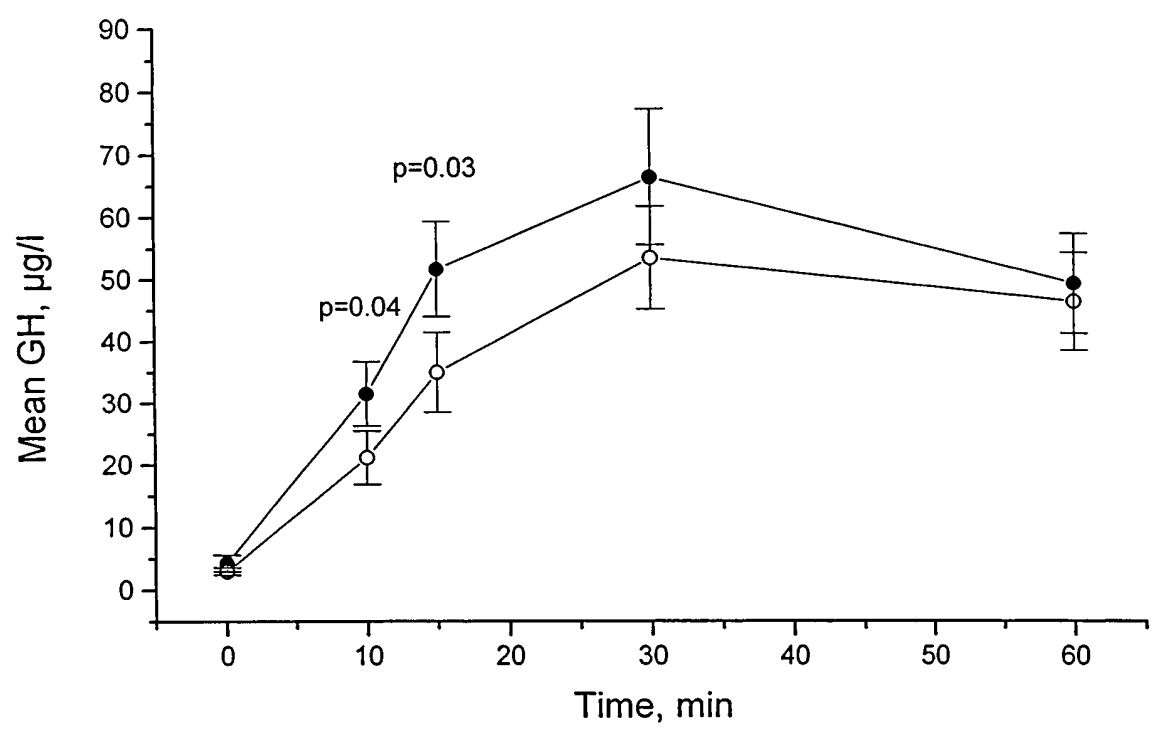

Figure $1 \mathrm{GH}$ responses in a GHRH stimulation test in children with hydrocephalus before $(\bullet)$ and after $(O)$ their first shunting operation. Three patients with a poor $\mathrm{GH}$ response (peak $\mathrm{GH}<10 \mu \mathrm{g} / \mathrm{l}$ ) were excluded.

whereas the decrease in the IGFBP-3 concentrations was lower in the younger age group $(-0.2 \mathrm{mg} / \mathrm{l}$ (range $-0.9-0.5 \mathrm{mg} / \mathrm{l}$ vs $-1.1 \mathrm{mg} / \mathrm{l}$ (range -1.5 to $0.9 \mathrm{mg} / \mathrm{l}$ ), $P<0.02$ ). Before the operation there were four patients with IGF-I concentrations below the reference values, while none had levels exceeding the reference range $(17,18)$. After the operation six patients had low IGF-I levels and none high levels in relation to the reference range. Two patients had IGFBP-3 concentrations exceeding the reference range before shunting, while only one had increased levels after the operation. IGFBP-3 levels below the reference range were seen in four patients before shunting and in seven children after the operation.

There was no significant difference between the LH AUC before the operation and after it $(174 \mathrm{U} / \mathrm{l} \cdot \mathrm{min}(35-$ $314 \mathrm{U} / \mathrm{l} \cdot \mathrm{min})$ vs $223 \mathrm{U} / \mathrm{l} \cdot \mathrm{min}(6-441 \mathrm{U} / \mathrm{l} \cdot \mathrm{min}, P=0.35$; Fig. 2A), although the actual mean concentrations were higher after the operation at all time points. The mean stimulated FSH levels were higher at $60 \mathrm{~min}$ (almost reaching significance, $P=0.06$; Fig. $2 \mathrm{~B}$ ) before the operation than afterwards. There were no significant differences in ACTH or cortisol responses, not even after the exclusion of the two patients who received dexamethasone before their first shunting operation. The TSH and PRL AUC were almost the same before and after the operation, as were serum testosterone and estradiol (data not shown). The increase in the LH AUC after the operation was higher in the oldest age group than in the youngest one $(325.7 \mathrm{U} / \mathrm{l} \cdot \mathrm{min}$ (range - 54.8$891.0 \mathrm{U} / \mathrm{l} \cdot \mathrm{min}$ ) vs $-49.4 \mathrm{U} / \mathrm{l} \cdot \mathrm{min}$ (range -331.596.8 U/l $\cdot \mathrm{min}), \mathrm{P}<0.05)$. No significant differences could be seen in the changes in FSH AUC, TSH AUC, PRL AUC, ACTH AUC or cortisol AUC after the operation between the patients older than 12 years of age and those younger than 1 year of age.

\section{Discussion}

We have shown in our earlier reports that children with shunt-treated hydrocephalus experience slow linear growth in prepuberty and accelerated pubertal maturation, ending up, when combined, in reduced final height $(19,20)$. A substantial proportion of the patients $(30 \%)$ had a reduced GH response to pharmacological stimuli, and their pituitary was small in size relative to both hydrocephalic patients with a normal GH response and age- and sex-matched controls (21). Since the basic mechanisms behind these phenomena remain to be defined, we set out to investigate pituitary function in children with newly diagnosed hydrocephalus before and after their first shunting operation to assess the possible effects of increased ICP on pituitary function.

As the number of patients in our series was limited, there is an obvious risk of type II errors, i.e. we may be unable to demonstrate 'true' significant differences. Another limitation is that we did not have access to 24-h monitoring data on ICP, which is known to change according to the position of the head and in the course of the day (22-24), so that it should be monitored continuously for at least $24 \mathrm{~h}$ to get reliable information on its mean level (25-27). The present patients were referred to our hospital when they had symptoms and signs of increased ICP and it was not considered ethically acceptable to wait for the results of continuous ICP monitoring, but rather they were operated on as soon as a diagnosis of hydrocephalus had been confirmed by other means. 

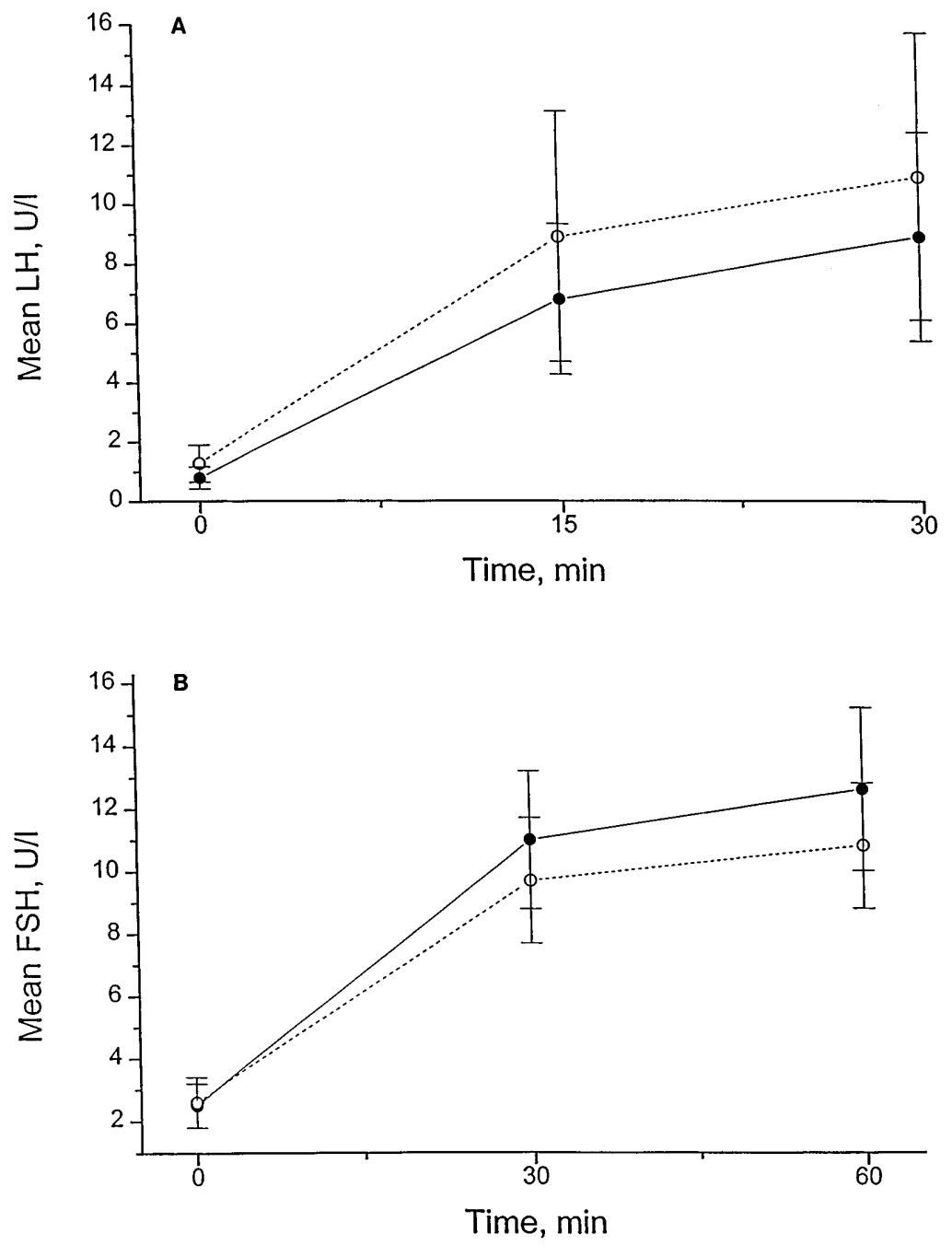

Figure 2 (A) LH and (B) FSH responses in a GnRH stimulation test in children with hydrocephalus before $(\bullet)$ and after $(O)$ their first shunting operation. One patient with the androgen insensitivity syndrome was excluded.

Nevertheless, we found signs of increased GH secretion before the shunting operation, indicating that an elevated ICP may stimulate $\mathrm{GH}$ synthesis and release. This idea is supported by the observation of higher IGFBP-3 levels before the operation than 6 weeks afterwards. It has been shown recently that the serum IGFBP-3 level is a good predictor of the GH response to a provocative test in short children (28).

We expected beforehand to find more dramatic effects of increased ICP on pituitary function. In addition to the enhanced GH response, there was a trend for an inhibition of LH secretion and a weak stimulation of FSH release. Taken together, these findings imply that elevated ICP may be related to stimulated GH secretion and inhibited LH release. This would suggest that, after the shunting operation, the reduced GH release and the early prepubertal induction of increased LH secretion seen by us previously in many children with shunted hydrocephalus $(18,21)$ may be the consequence of a decreased average ICP and/or the absence of physiological pressure fluctuations in such patients. If this is the case, it emphasizes the importance of developing more physiological shunts. An argument that could be used against the hypothesis of an inhibitory effect of decreased ICP on GH secretion is that we could not find any difference in linear growth between the patients with the slit ventricle syndrome (SLVS) and those with no signs of SLVS in our previous retrospective survey (19). A prospective study with parallel monitoring of growth velocities and emerging signs of the SVLS would be needed, however, to define whether SVLS is associated with growth retardation.

\section{Acknowledgements}

We thank Ms Sirpa Anttila and Ms Riitta Päkkilä for their skilful technical assistance. This work was 
supported by the Sigrid Jusélius Foundation, Helsinki, Finland ( $\mathrm{T}$ L, M K), the Alma and K A Snellman Foundation, Oulu, Finland (T L), the Arvo and Lea Ylppö Foundation, Helsinki, Finland (T L) and the Foundation for Pediatric Research in Finland (T L).

\section{References}

1 De Luca F, Muritano M, Rizzo G, Pandullo E \& Cardia E. True precocious puberty: a long-term complication in children with shunted non-tumoral hydrocephalus. Helvetica Paediatrica Acta $198540467-472$.

2 Brauner R, Rappaport R, Nicod C, Malandry F, Thibaud E, PierreKhan A et al. True precocious puberty in children with nontumoral hydrocephalus. Analysis of 16 cases. Archives Francaises de Pediatrie 198744 433-436.

3 Kaiser G, Ruedeberg A \& Arnold M. Endocrinological disorders in shunted hydrocephalus. Zeitschrift für Kinderchirurgie 198944 (Suppl 1) 16-17

4 Tomono Y, Maki Y, Ito M \& Nakada Y. Precocious puberty due to postmeningitic hydrocephalus. Brain and Development 19835 $414-417$.

5 Stanhope R \& Brook CGD. Disorders of puberty. In Clinical Paediatric Endocrinology, edn 3, pp 189-212. Ed CGD Brook. Oxford: Blackwell Scientific Publications, 1989.

6 Fiedler R \& Krieger DT. Endocrine disturbances in patients with congenital aqueductal stenosis. Acta Endocrinologica 1975801 13.

7 Caporal R, Segrestaa M \& Dorf G. Endocrine expression of hydrocephalus. A case of primary amenorrhea revealing a stenosis of foramen of Magendie. Acta Endocrinologica 1983102 $161-166$.

8 Kulali A, Baykut L \& von Wild K. Relationship between chronic raised intracranial pressure and empty sella presenting hormona disturbances. Neurological Research 1990 12 99-102.

9 Amacher AL \& Wellington J. Infantile hydrocephalus: long-term results of surgical therapy. Childs Brain 198411 217-229.

10 Sorva R, Perheentupa J \& Tolppanen EM. New format for a growth chart. Acta Paediatrica Scandinavica 198473 527-529.

11 Kantero RL \& Tiisala R. Growth of head circumference from birth to 10 years. Acta Paediatrica Scandinavica 1971220 427-432.

12 Perheentupa J \& Dunkel L. Endocrinology of childhood and adolescence (in Finnish). In Clinical Endocrinology, edn 2, pp 484591. Eds B-A Lamberg, V Koivisto \& R Pelkonen. Helsinki: Duodecim, 1992.

13 Tanner JM \& Whitehouse RH. Clinical longitudinal standards for height, weight, height velocity and stages of puberty. Archives of Disease in Childhood 197651 170-182.

14 Greulich WW \& Pyle SI. Radiographic Atlas of Skeletal Development of the Hand and Wrist. Stanford, California: Stanford University Press, 1959.
15 Elgenmark O. The normal development of the ossific centres during infancy and childhood. A clinical, roentgenologic and statistical study. Acta Paediatrica 194633 1-79.

16 Tapanainen P. Growth hormone $(\mathrm{GH})$ response to GH-releasing hormone and plasma GH-releasing hormone concentrations in short children. European Journal of Pediatrics $1993152984-989$.

17 Nuutinen M, Kouvalainen K \& Knip M. Good growth response to growth hormone treatment in the ring chromosome 15 syndrome. Journal of Medical Genetics 199532 486-487.

18 Löppönen T, Saukkonen A-L, Serlo W, Tapanainen P, Ruokonen A \& Knip M. Reduced levels of growth hormone, insulin-like growth factors-I and binding protein-3 in patients with shunted hydrocephalus. Archives of Disease in Childhood 199777 32-37.

19 Löppönen T, Saukkonen A-L, Serlo W, Lanning P \& Knip M. Slow prepubertal linear growth but early pubertal growth spurt in patients with shunted hydrocephalus. Pediatrics 199595 917-923.

20 Löppönen T, Saukkonen A-L, Serlo W, Tapanainen P, Ruokonen A \& Knip M. Accelerated pubertal development in patients with shunted hydrocephalus. Archives of Disease in Childhood 199675 490-496.

21 Löppönen T, Pääkkö E, Laitinen J, Saukkonen A-L, Serlo W, Tapanainen $\mathrm{P}$ et al. Pituitary size and function in children and adolescents with shunted hydrocephalus. Clinical Endocrinology 199746 691-699.

22 Trost HA. Is there a reasonable differential indication for different hydrocephalus shunt systems? Childs Nervous System 199511 189-192.

23 Kadowaki C, Hara M, Numoto M, Takeuchi K \& Saito I. CSF shunt physics: factors influencing in shunt CSF flow. Childs Nervous System $199511203-206$.

24 Chapman PH, Cosman ER \& Arnold MA. The relationship between ventricular fluid pressure and body position in normal subjects and subjects with shunts: a telemetric study. Neurosurgery $199026181-189$.

25 Di Rocco C, McLone DG, Shimoji T \& Raimondi AJ. Continuous intraventricular cerebrospinal fluid pressure recordings in hydrocephalic children during wakefulness and sleep. Journal of Neurosurgery 197542 683-689.

26 Shapiro K, Marmarou A \& Shulman K. Abnormal brain biomechanics in the hydrocephalic children. Pediatric Neurosurgery $199319216-223$.

27 Fouyas IP, Casey AT, Thompson D, Harkness WF \& Hayward RD. Use of intracranial pressure monitoring in the management of childhood hydrocephalus and shunt-related problems. Neurosurgery $199638726-731$.

28 Juul A \& Skakkebaek NE. Prediction of the outcome of growth hormone provocative testing in short children by measurement of serum levels of insulin-like growth factor-I and insulin-like growth factor binding protein-3. Journal of Pediatrics 1997130 197-204.

Received 15 July 1997

Accepted 31 October 1997 